Pacific Journal of Mathematics

ANOTHER MARTINGALE CONVERGENCE THEOREM 


\title{
ANOTHER MARTINGALE CONVERGENCE THEOREM
}

\author{
A. G. MuCCI
}

A classical martingale theorem is generalized to "martingale like" sequences. The method of proof is a generalization of Doob's proof by "downcrossings".

Introduction. Let $(\Omega, B, P)$ be a probability space, $\left\{B_{n}\right\}$ an increasing sequence of sub sigma fields of $B$. Let $\left\{f_{n}, B_{n}, n \geqq 1\right\}$ be an adapted sequence of $P$-integrable random variables.

The sequence is said to be a martingale in the limit if

$$
\lim _{n \rightarrow \infty} \sup _{\bar{n}>n}\left|f_{n}-E\left(f_{\bar{n}} \mid B_{n}\right)\right|=0 \quad P \quad \text { a.e. }
$$

If was proven in an earlier paper, Mucci [3] that every uniformly integrable martingale in the limit converges both $L_{1}$ and $P$ a.e., generalizing the corresponding martingale theorem. The purpose of the present note is to prove that every $L_{1}$-bounded martingale in the limit converges pointwise to an integrable random variable, thereby generalizing another classical martingale theorem. We recall that a sequence $\left\{f_{n}\right\}$ is said to be $L_{1}$-bounded if $\sup _{n} \int\left|f_{n}\right|<\infty$.

THE THEOREM. Let $\left\{f_{n}, B_{n}, n \geqq 1\right\}$ be an $L_{1}$-bounded martingale in the limit. Then there exists $f \in L_{1}$ with $f_{n} \rightarrow f P$ a.e.

Proof. Fix $a<b$, two arbitrary real numbers. We define, following the classical proof:

$\varphi(a, b)$ is the number of "downcrossings" of $\left\{f_{n}\right\}$ from above $b$ to below $a$. Our objective will be to show that $P(\varphi(a, b)=\infty)=0$ so that $P\left(\lim f_{n} \leqq a<b \leqq \varlimsup \lim f_{n}\right)=0$, thereby determining that $f=\lim _{n} f_{n}$ exists almost everywhere, and since

$$
\int|f|<\underline{\lim } \int\left|f_{n}\right|<\infty ; \text { that } f \in L_{1} \text {. }
$$

Our procedure consists in defining a "modified" number of downcrossings $\bar{\varphi}(a, b)$ and showing that $P(\bar{\varphi}(a, b)=\infty)=0$ and further that, almost everywhere,

$$
\bar{\varphi}(a, b)<\infty \text { implies } \varphi(a, b)<\infty .
$$


We begin by defining a sequence of stopping times:

$$
\tau_{0}=0
$$

Now let $\left\{\alpha_{n}\right\}$ be a decreasing sequence of positive numbers with $\sum \alpha_{n}<\infty$, and let $N$ be a fixed positive integer.

Define $\tau_{2 n-1}$ as the first $m \leqq N$ such that:
(1) $m>\tau_{2 n-2}$
(2) $f_{m}>b$
(3) $\sup _{\bar{m}>m}\left|f_{m}-E\left(f_{m} \mid B_{m}\right)\right|<\alpha_{n}$.

If no such $m$ exists, set $\tau_{2 n-1}=N$.

Likewise, define $\tau_{2 n}$ as the first $m \leqq N$ such that:
(1) $m>\tau_{2 n-1}$
()ㅡ $f_{m}<a$

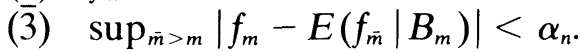

If no such $m$ exists, set $\tau_{2 n}=N$. We have

$$
\begin{aligned}
\int f_{\tau_{2 n-1}}-\int f_{\tau_{2 n}}= & \sum_{1}^{N} \int_{\left(\tau_{2 n-1}=k\right)}\left(f_{k}-E\left(f_{N} \mid B_{k}\right)\right) \\
& +\sum_{1}^{N} \int_{\left(\tau_{2 n}=k\right)}\left(E\left(f_{N} \mid B_{k}\right)-f_{k}\right)<2 \alpha_{n} .
\end{aligned}
$$

Thus

$$
\sum_{1}^{\infty} \int\left(f_{\tau_{2 n-1}}-f_{\tau_{2 n}}\right)<2 \sum_{1}^{\infty} \alpha_{n}=2 \alpha
$$

We want an inequality in the other direction.

Define

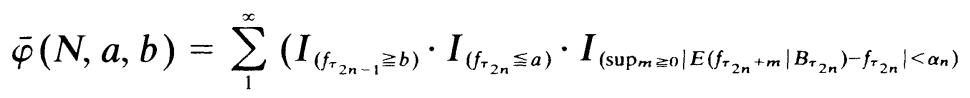

the number of times we make a "downcrossing" subject to conditions (3),

$(\overline{3})$ on our stopping times.

We have

$$
\sum_{1}^{\infty}\left(f_{\tau_{2 n-1}}-f_{\tau_{2 n}}\right) \geqq(b-a) \bar{\varphi}(N, a, b)-|b|-\left|f_{N}\right| .
$$

Taking integrals, defining

$$
\bar{\varphi}(a, b)=\lim _{N \rightarrow \infty} \bar{\varphi}(N, a, b)
$$


and using Fatou's lemma and $(*)$, we have

$(* *) \quad \int \bar{\varphi}(a, b)<\frac{1}{b-a}\left[|b|+2 \alpha+\sup _{n} \int\left|f_{n}\right|\right]<\infty$.

Therefore $P(\bar{\varphi}(a, b)<\infty)=1$.

Let us now define

$$
\Omega_{0}=(\bar{\varphi}(a, b)<\infty) \cap\left(\lim _{n \rightarrow \infty} \sup _{\bar{n}>n}\left|f_{n}-E\left(f_{\bar{n}} \mid B_{n}\right)\right|=0\right) .
$$

Clearly $P\left(\Omega_{0}\right)=1$ and we will be finished if we can show that $\varphi(a, b)<\infty$ on $\Omega_{0}$. Now, for a particular $\omega \in \Omega_{0}$, let $\bar{\varphi}(a, b)=M$. Suppose $\varphi(a, b)=$ $\infty$.

Then we can find a sequence $\left\{n_{k}\right\}$ where $f_{n_{2 k-1}} \geqq b, f_{n_{2 k}} \leqq a$ and where (3), $(\overline{3})$ hold. This contradicts $\bar{\varphi}(a, b)=M$.

Corollary 1. Let $\left\{f_{n}, B_{n}, n \geqq 1\right\}$ be a martingale in the limit, and let $r \geqq 1$. Then there exists $f \in L_{r}$ such that $f_{n} \rightarrow f$ both $P$ a.e. and in the $L_{r}-$ norm $\Leftrightarrow\left\{\left|f_{n}\right|^{r}\right\}$ is uniformly integrable.

Proof. If $\left\{\left|f_{n}\right|^{r}\right\}$ is uniformly integrable, then $\left\{f_{n}, B_{n}\right\}$ is $L_{1}$-bounded, hence $f_{n} \rightarrow f P$ a.e. The rest follows by the usual classical arguments. (See Neveu, p. 57.)

COROLlary 2. Let $s_{n}=\sum_{1}^{n} \xi_{k}$ where $\left\{\xi_{k}\right\}$ is an independent sequence. Then $s_{n} \rightarrow s \in L_{1}$ both $P$ a.e. and $L_{1}$ provided $\left\{s_{n}\right\}$ is Cauchy in the $L_{1}$-norm.

Proof. The Cauchy condition is equivalent to $\left\{s_{n}, B_{n}, n \geqq 1\right\}$ being a martingale in the limit (here $B_{n}=\sigma\left(\xi_{1} \cdots \xi_{n}\right)$ ). Further,

$$
\sup _{n} \int\left|s_{n}\right| \leqq \int\left|s_{M}\right|+\sup _{n \geqq M} \int\left|s_{n}-s_{M}\right|<\infty
$$

\section{REFERENCES}

1. L. Blake, A generalization of martingales and two consequent convergence theorems, Pacific J. Math., 35 (1970), 279-283.

2. J. Neveu, Mathematical Foundations of the Calculus of Probability, Holden Day (1965).

3. A. G. Mucci, Limits for martingale-like sequences, Pacific J. Math, 48 (1973), 197-202.

4. R. Subramanian, On a generalization of martingales due to Blake, Pacific J. Math., 48 (1973), 275-278.

Received July 28, 1975 and in revised form January 13, 1976. 



\section{PACIFIC JOURNAL OF MATHEMATICS}

\section{EDITORS}

RICHARD ARENS (Managing Editor)

University of California

Los Angeles, California 90024

\author{
R. A. Beaumont \\ University of Washington \\ Seattle, Washington 98105
}

\section{J. DugunduI}

Department of Mathematics University of Southern California Los Angeles, California 90007

D. Gilbarg and J. Milgram

Stanford University

Stanford, California 94305

\section{ASSOCIATE EDITORS}

E. F. BECKENBACH
B. H. NeumanN

F. Wolp
K. YoshidA

\section{SUPPORTING INSTITUTIONS}

UNIVERSITY OF BRITISH COLUMBIA

CALIFORNIA INSTITUTE OF TECHNOLOGY

UNIVERSITY OF CALIFORNIA

MONTANA STATE UNIVERSITY

UNIVERSITY OF NEVADA

NEW MEXICO STATE UNIVERSITY

OREGON STATE UNIVERSITY

UNIVERSITY OF OREGON

OSAKA UNIVERSITY

\author{
UNIVERSITY OF SOUTHERN CALIFORNIA \\ STANFORD UNIVERSITY \\ UNIVERSITY OF HAWAII \\ UNIVERSITY OF TOKYO \\ UNIVERSITY OF UTAH \\ WASHINGTON STATE UNIVERSITY \\ UNIVERSITY OF WASHINGTON \\ AMERICAN MATHEMATICAL SOCIETY
}

The Supporting Institutions listed above contribute to the cost of publication of this Journal, but they are not owners or publishers and have no responsibility for its contents or policies.

Mathematical papers intended for publication in the Pacific Journal of Mathematics should be in typed form or offset-reproduced (not dittoed). double spaced with large margins. Underline Greek letters in red, German in green, and script in blue. The first paragraph or two must be capable of being used separately as a synopsis of the entire paper. Items of the biblography should not be cited there unless absolutely necessary, in which case they must be identified by author and Journal, rather than by item number. Manuscripts, in duplicate, may be sent to any one of the four editors. Please classify according to the scheme of Math. Reviews, Index to Vol. 39. All other communications should be addressed to the managing editor, or Elaine Barth, University of California, Los Angeles, California, 90024.

100 reprints are provided free for each article, only if page charges have been substantially paid. Additional copies may be obtained at cost in multiples of 50 .

The Pacific Journal of Mathematics is issued monthly as of January 1966. Regular subscription rate: $\$ 72.00$ a year (6 Vols., 12 issues). Special rate: $\$ 36.00$ a year to individual members of supporting institutions.

Subscriptions, orders for back numbers, and changes of address should be sent to Pacific Journal of Mathematics, 103 Highland Boulevard, Berkeley, California, 94708.

PUBLISHED BY PACIFIC JOURNAL OF MATHEMATICS, A NON-PROFIT CORPORATION Printed at Jerusalem Academic Press, POB 2390, Jerusalem, Israel.

Copyright (C) 1976 Pacific Journal of Mathematics All Rights Reserved 


\section{Pacific Journal of Mathematics}

\section{Vol. 64, No. $2 \quad$ June, 1976}

Richard Fairbanks Arnold and A. P. Morse, Plus and times............. 297

Edwin Ogilvie Buchman and F. A. Valentine, External visibility ......... 333

R. A. Czerwinski, Bonded quadratic division algebras.............. 341

William Richard Emerson, Averaging strongly subadditive set functions in unimodular amenable groups. II .........................

Lynn Harry Erbe, Existence of oscillatory solutions and asymptotic behavior for a class of third order linear differential equations ............. 369

Kenneth R. Goodearl, Power-cancellation of groups and modules........ 387

J. C. Hankins and Roy Martin Rakestraw, The extremal structure of locally compact convex sets ...................................

Burrell Washington Helton, The solution of a Stieltjes-Volterra integral

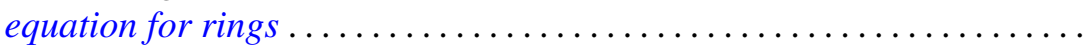

Frank Kwang-Ming Hwang and Shen Lin, Construction of 2-balanced

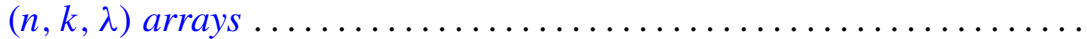

Wei-Eihn Kuan, Some results on normality of a graded ring ... 455

Dieter Landers and Lothar Rogge, Relations between convergence of series and convergence of sequences ......................... 465

Lawrence Louis Larmore and Robert David Rigdon, Enumerating immersions and embeddings of projective spaces ................

Douglas C. McMahon, On the role of an abelian phase group in relativized problems in topological dynamics..................

Robert Wilmer Miller, Finitely generated projective modules and TTF classes...

Yashaswini Deval Mittal, A class of isotropic covariance functions ...

Anthony G. Mucci, Another martingale convergence theorem ...

Joan Kathryn Plastiras, Quasitriangular operator algebras ...

John Robert Quine, Jr., The geometry of $p\left(S^{1}\right) \ldots \ldots \ldots$. 